\title{
Genetic divergence among Brazilian turmeric germplasm using morpho-agronomical descriptors
}

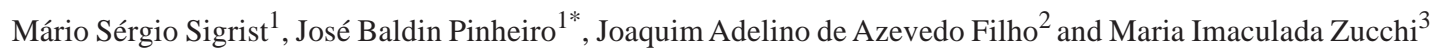

Received 18 May 2010

Accepted 23 July 2010

\begin{abstract}
Turmeric (Curcuma longa L.) is a vegetatively-propagated crop which is used as a natural dye in the food industry and also presents many biological active compounds. Turmeric conventional breeding is difficult and often limited to germplasm selection. The aim of this study was to evaluate the genetic divergence among turmeric accessions available in Brazil using seven morpho-agronomical descriptors. Overall genetic divergence was low, although some divergent genotypes were identified. Four main groups of genotypes were identified and could be further used in breeding programs. Canonical variable analysis suggested that some descriptors were more important to discriminate accessions and also that one of the descriptors could be discarded. The results provided useful insights for better management of the germplasm collection, optimizing conservational and breeding efforts.
\end{abstract}

Key words: Curcuma longa, medicinal plant, natural dye, genetic resources, multivariate analysis.

\section{INTRODUCTION}

Curcuma longa L., commonly known as turmeric, is a tropical perennial herb belonging to the family Zingiberaceae. Commonly used as a spice and natural food dye, it is mainly cultivated in Southeast Asia and India appears as the largest producer and exporter. In Brazil, the crop is mainly cultivated by small farmers in the State of Goiás, near Mara Rosa city. However, due to the increasing demand for $C$. longa derived products, the crop may expand over new areas.

Commonly used as a spice and natural food dye, turmeric powder is obtained from $C$. longa rhizomes which, after drying and processing, results in a bright yellow powder valued as a natural food dye (Cecílio-Filho et al.
2000). Its bright yellow color is due to the presence of curcumin pigment, which is also a powerful antioxidant, anti-parasitic, antispasmodic, anti-inflammatory and anticarcinogenic compound (Sasikumar 2005, Ravindran et al. 2007). Consequently, turmeric shows a great potential for the development of new cosmetics and drugs.

Turmeric is a cross-pollinated, triploid species $(2 n=$ $3 x=63$ ), which can be vegetatively-propagated using its underground rizhomes (Sasikumar 2005). Since hybridization is ineffective in most cases, genetic improvement is often limited to germplasm selection and mutation breeding (Ravindran et al. 2007). Viable seed sets can be obtained under certain conditions, which enables recombination breeding through hybridization and open-pollinated progeny selection (Sasikumar 2005). Recently, other

\footnotetext{
${ }^{1}$ Universidade de São Paulo (ESALQ), Departamento de Genética, 13400-970, Piracicaba, SP, Brazil. *E-mail: baldin@esalq.usp.br

2 Polo APTA, Regional Leste Paulista, 13910-000, Monte Alegre do Sul, SP, Brazil

${ }^{3}$ Agência Paulista de Tecnologia dos Agronegócios, 13400-970, Piracicaba, SP, Brazil
} 
alternatives have been successfully employed such as somaclonal variations, mutation breeding, induction of polyploidy and genetic engineering (Shirgurkar et al. 2006).

Because germplasm collections represents the main source of variability for turmeric genetic improvement, efforts to characterize these collections have been specially conducted in India, where the crop is economically important and most of the genetic diversity is found (Chandra et al. 1997, Lynrah et al. 1998, Singh et al. 2003, Chaudhary et al. 2006). In Brazil, the largest turmeric collection is maintained by the Department of Genetics of the University of São Paulo, located in Piracicaba (SP). Pinheiro et al. (2003) were the first to evaluate the genetic diversity of this collection using random amplified polymorphic DNA markers (RAPD) to screen 20 accessions. The genetic divergence among these accessions was later estimated in field experiments by Cintra et al. (2005). As a result, both studies found a low genetic variability in the collection, suggesting that the introduction of new accessions should be a priority. After the inclusion of more genotypes, Sigrist et al. (2009), using microsatellite markers (SSR), indicated a slight increase in variability. However, most of the new genotypes had not been evaluated under field conditions to date.

Since knowledge of the genetic variation in the turmeric germplasm is essential to optimize the exploitation of genetic resources, the present study intended to estimate the genetic divergence among 32 turmeric accessions, which represents most of the diversity currently available in Brazil.

\section{MATERIAL AND METHODS}

Curcuma longa genotypes were obtained from the Department of Genetics of the University of São Paulo (USP - ESALQ). Field experiments were performed at the same time (November, 2007 until July, 2008) in two different locations. The first experiment was held in Piracicaba, SP (lat 22 $45^{\prime} \mathrm{S}$, long $47^{\circ} 38^{\prime} \mathrm{W}$ ) and the second in Monte Alegre do Sul, SP (lat 22 $43^{\prime}$ S, long $46^{\circ} 37^{\prime} \mathrm{W}$ ). Third-two accessions from the States of Goiás, São Paulo and Minas Gerais (Table 1) were arranged in a complete randomized blocks design with five repetitions. In each block, rhizomes of the same size were planted, since this character is known to influence productivity (Maia et al. 1995, Hossaim et al. 2005). Experimental plots were represented by two rows of five meters; with rows spaced $0.5 \mathrm{~m}$ and plants $0.2 \mathrm{~m}$ apart. The following descriptors were evaluated: plant height, tiller number, number of heads, weight of heads, number of fingers, weight of fingers and total weight.
Table 1. List of Curcuma longa accessions studied and their origin in Brazil

\begin{tabular}{|c|c|c|c|}
\hline ID & Accession & State $^{1}$ & City \\
\hline 1 & 0424MG & MG & $\mathrm{N} / \mathrm{A}^{2}$ \\
\hline 2 & MR1 & $\mathrm{GO}$ & Mara Rosa \\
\hline 3 & MR2 & $\mathrm{GO}$ & Mara Rosa \\
\hline 4 & MR3 & GO & Mara Rosa \\
\hline 5 & MGSN & MG & N/A \\
\hline 6 & MR4 & GO & Mara Rosa \\
\hline 7 & MR5 & $\mathrm{GO}$ & Mara Rosa \\
\hline 8 & MR6 & $\mathrm{GO}$ & Mara Rosa \\
\hline 9 & SR & $\mathrm{GO}$ & Santa Rosa \\
\hline 10 & MR9 & $\mathrm{GO}$ & Mara Rosa \\
\hline 11 & IAC22 & SP & Campinas \\
\hline 12 & LVR & MG & Lavras \\
\hline 13 & MR10 & $\mathrm{GO}$ & Mara Rosa \\
\hline 14 & MR11 & $\mathrm{GO}$ & Mara Rosa \\
\hline 15 & RUB & $\mathrm{GO}$ & Rubiataba \\
\hline 16 & MR13 & $\mathrm{GO}$ & Mara Rosa \\
\hline 17 & MGM24 & MG & N/A \\
\hline 18 & MR14 & GO & Mara Rosa \\
\hline 19 & M22-B & SP & Campinas \\
\hline 20 & HENR & $\mathrm{GO}$ & Goiânia \\
\hline 21 & MR15 & $\mathrm{GO}$ & Mara Rosa \\
\hline 22 & MR16 & $\mathrm{GO}$ & Mara Rosa \\
\hline 23 & MR17 & $\mathrm{GO}$ & Mara Rosa \\
\hline 24 & IBI & SP & Ibitinga \\
\hline 25 & MR18 & GO & Mara Rosa \\
\hline 26 & BOT & SP & Botucatu \\
\hline 27 & IACM25 & SP & Campinas \\
\hline 28 & MR19 & GO & Mara Rosa \\
\hline 29 & GOI & $\mathrm{GO}$ & N/A \\
\hline 30 & $\mathrm{MG}$ & MG & N/A \\
\hline 31 & IAC7 & SP & Campinas \\
\hline 32 & IAC6(+) & SP & Campinas \\
\hline
\end{tabular}

A multivariate analysis was performed, applying the techniques of clustering and of canonical variables. In all analysis, data from both locations were combined to obtain means, variance and covariance matrices. Clustering was performed using Mahalanobis' generalized distance as a measure of dissimilarity and genotype groupings were obtained using the UPGMA method. For comparison, the Tocher optimization algorithm was also used to obtain groups (Rao 1952).

In the analysis of canonical variables, the genetic divergence was evidenced by the graphic dispersion of the accessions in relation to the first and second canonical variables, which represents most of the variation observed. The relative importance of each canonical variable and of the descriptors in the prediction of genetic divergence 
MS Sigrist et al.

was also estimated, following Cruz and Regazzi (2001). All statistical analyses were performed using the software Genes (Cruz 2001).

\section{RESULTS AND DISCUSSION}

Estimations of the genetic divergence, using a multivariate analysis of both clustering (UPGMA) and optimization (Tocher) methods, shows a pattern of four main groups: I) comprising most accessions, with genotypes MR2, SR and MGSN being the most divergent; II) MR19 and GOI; III) IBI; IV) IAC6(+) (Figure 1). Although the relative position of a few genotypes are slightly different under both methods, overall correspondence among hierarchical and optimization clusters indicates that these main groups are well corroborated. Dendrogram's cophenetic value was 0.74 , demonstrating a good correspondence between the raw data and the original matrix.

The first outcome of the dendrogram is that the genetic divergence is not related to the origin of the accessions and thus, the variability is not spatially structured (i.e. group I comprised genotypes from different States). A similar result was found by Pinheiro et al. (2003) and Sigrist et al. (2009) using molecular markers, where most of the genetic variation was found to be within States. Indeed, this lack of spatial structure was expected, since the crop introduction in Brazil is relatively recent (Pinheiro et al. 2003).

All accessions used in the present study were also tested by Sigrist et al. (2009) using simple sequence repeat markers (SSR). Comparing both results, it is possible to conclude that the morpho-agronomical evaluation allowed a better partition of the accessions in groups. For example, most of the genotypes evaluated here were placed within one large group determined using SSR markers. This information strengthens the need for a wide variety of approaches to fully characterize the genetic resources (Valois 2001).

Another important consequence of the dendrogram is that most accessions collected in Mara Rosa have a low genetic divergence, suggesting that farmers may be using a mixture of similar clones. This shortcoming was also observed by Pinheiro et al. (2003) and Cintra et al. (2005), who suggested that this low genetic variability might be limiting the yield potential of the largest producing region in Brazil. However, it was possible to identify some divergent accessions within the Mara Rosa region: MR2, MR19, SR and GOI. Among these, accession SR was also indicated as divergent using RAPD markers (Pinheiro et al. 2003).

The only accession that appears as highly divergent in all characterization studies conducted so far is IAC6(+), which has also been evidenced by molecular markers (Sigrist et al. 2009). This genotype was developed through clonal selection and is characterized by high levels of curcumin content, which is an important characteristic for turmeric breeding. This is the only breeding method performed in Brazil to date and, according to the results; this accession might be regarded as a promising material for future breeding programs.

In the canonical variable analysis, the eigenvalue estimates corresponding to the two first canonical variables explained $84.61 \%$ of the total variation (Table 2). This high value indicates that the two-dimensional graphical representation is ap-propriate for viewing the relationship among groups and among accessions within the groups, allowing to describe the genetic divergence among accessions (Cruz and Regazzi 2001) (Figure 2). This analysis presented some slightly different results from clustering methods, with the Tocher groupings dispersed and not so clearly defined. However, in spite of the observed discrepancies among the methodology analyzed, it was possible to recognize dissimilar genotypes (i.e. IAC6+).

The relative contributions of descriptors to the genetic divergence of the 32 turmeric accessions are also described in Table 2. According to Cruz and Regazzi (2001), the module of the highest scores in the first 2 canonical variables, which are responsible for most of the variation, may indicate which descriptors are important to discriminate accessions. In the first canonical variable, descriptors weight of fingers, number of fingers and total weight presented the highest scores and in the second canonical variable the most important descriptors were tiller number and number of heads. In the same way as other studies, these characteristics can be regarded as the most important to discriminate turmeric accessions (Linrah et al. 1998, Chandra et al. 1997, Singh et al. 2003). On the other hand, Cintra et al. (2005) suggested that these descriptors together contributed to only $16.52 \%$ of the evaluation of genetic divergence. According to these authors, most important were the curcumin content and the total dry weight. Considering that these descriptors are important for turmeric breeding (Sasikumar 2005) they should be evaluated in further studies.

In addition, canonical variable analysis may also indicate which descriptors could be discarded, facilitating 


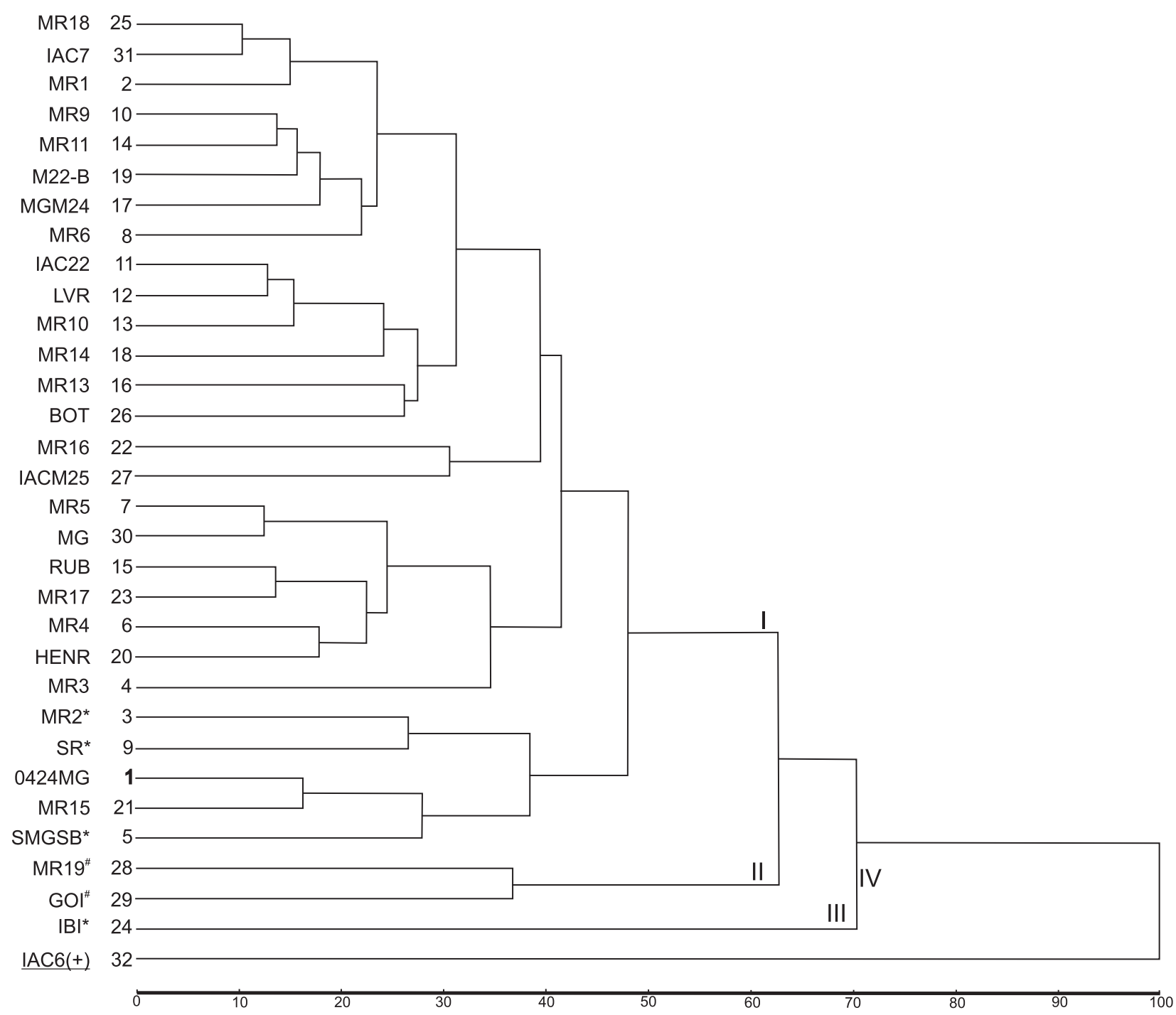

Figure 1. Dendrogram representing the genetic divergence among turmeric accessions (UPGMA). Roman numerals indicate the four main groups. For comparison, the groupings according to Tocher optimization algorithm are represented as follows: group 1 (no symbol), group $2(*)$, group $3(*)$ and group 4 (underlined). For accession identification, see Table 1.

Table 2. Canonical variables obtained from the analysis of seven descriptors transformed using pivotal condensation

\begin{tabular}{cccccccccc}
\hline \multirow{2}{*}{$\begin{array}{c}\text { Canonical } \\
\text { variable }\end{array}$} & \multirow{2}{*}{$\begin{array}{c}\text { Root } \\
(\%)\end{array}$} & $\begin{array}{c}\text { Accumulated } \\
\text { variance (\%) }\end{array}$ & \multicolumn{6}{c}{ Importance of the descriptors* in each canonical variable } \\
\cline { 5 - 10 } & & $\mathbf{X} 1$ & $\mathbf{X 2}$ & $\mathbf{X 3}$ & $\mathbf{X 4}$ & $\mathbf{X 5}$ & $\mathbf{X 6}$ & $\mathbf{X} 7$ \\
\hline VC1 & 74.10 & 74.10 & 0.215 & 0.206 & 0.244 & 0.339 & 0.422 & 0.530 & 0.520 \\
VC2 & 10.51 & 84.61 & 0.018 & 0.822 & 0.372 & 0.166 & 0067 & 0.332 & 0.209 \\
VC3 & 7.50 & 92.11 & 0.726 & 0.297 & 0.418 & 0.216 & 0.367 & 0.158 & 0.056 \\
VC4 & 4.66 & 96.77 & 0.435 & 0.413 & 0.382 & 0.556 & 0.348 & 0.251 & 0.024 \\
VC5 & 2.74 & 99.52 & 0.486 & 0.136 & 0.180 & 0.316 & 0.673 & 0.263 & 0.304 \\
VC6 & 0.47 & 100 & 0.005 & 0.075 & 0.670 & 0.587 & 0.330 & 0.303 & 0.055 \\
VC7 & 0 & 100 & 0 & 0 & 0 & -0.237 & 0 & -0.599 & 0.766 \\
\hline
\end{tabular}

* $\mathrm{X}_{1}=$ Plant height; $\mathrm{X}_{2}=$ tiller number; $\mathrm{X}_{3}=$ Number of heads; $\mathrm{X}_{4}=$ Weight of heads; $\mathrm{X}_{5}=$ Number of fingers; $\mathrm{X}_{6}=$ Weight of fingers; $\mathrm{X}_{7}=$ Total weight. 
MS Sigrist et al.

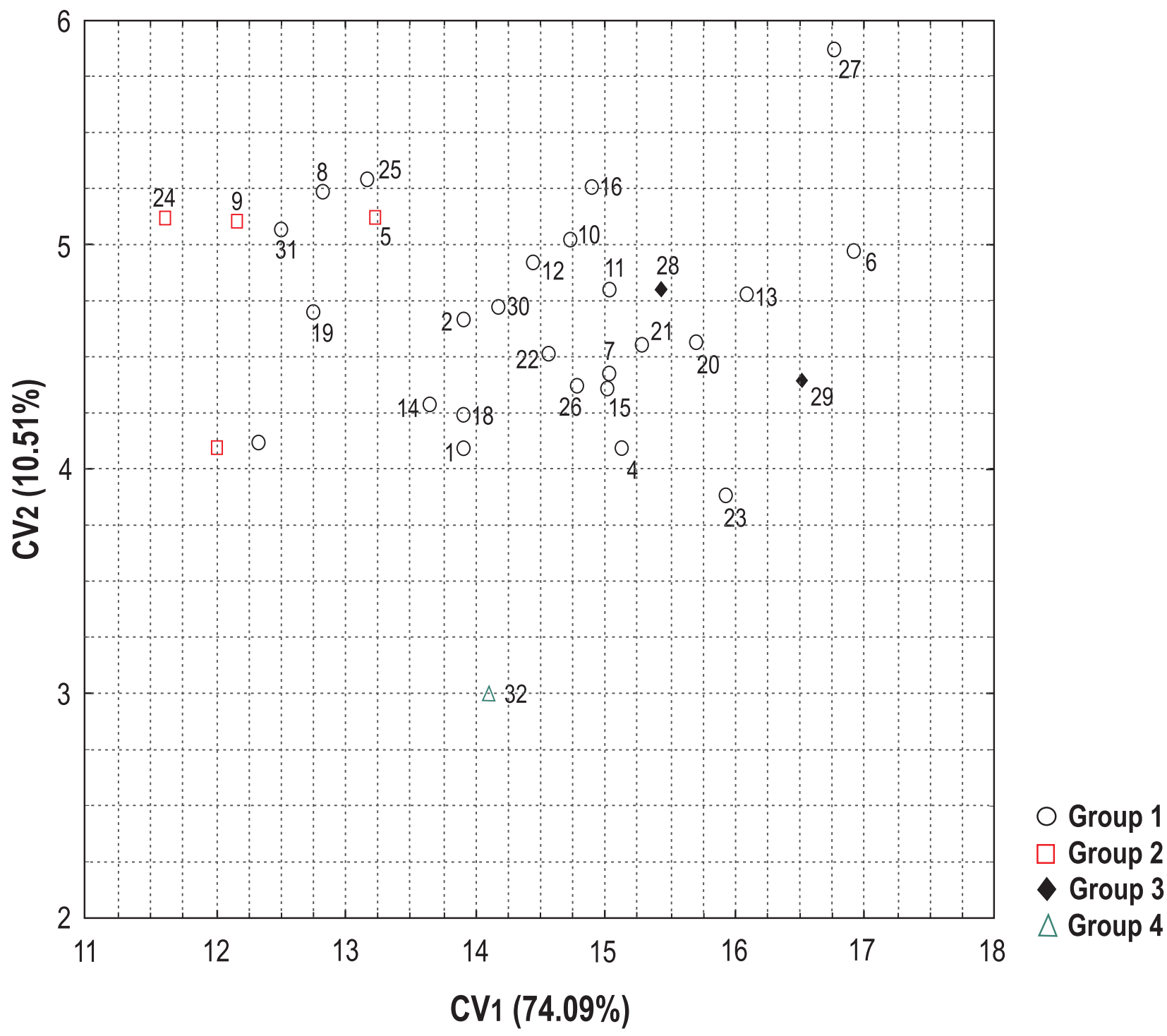

Figure 2. Graphic dispersion of the accessions considering the first two canonical variables (CV1 and CV2). Values of the variation percentages obtained for each canonical variable are indicated in brackets. See table 1 for accession identification.

field evaluations. In Table 2, it is possible to verify that the last canonical variable still presents scores different from zero. This suggests that the descriptors weight of fingers, weight of heads and total weight are strongly correlated and thus, one of them could be discarded (i.e. descriptor weight of heads). Considering that the turmeric collection is maintained in vivo and that most materials are genetically similar, it should be possible to compose a mixed sample of highly related accessions, aiding to decrease the costs of the collection management. Comparing the genetic divergence obtained using molecular end morphoagronomical markers, maybe four or five pools of genotypes would be sufficient to represent the genetic variability within and between accessions of the collection. However, it should be emphasized that other important descriptors still need to be evaluated before these pools are made. Another interesting way to preserve the materials is in vitro propagation, which may also allow finding useful somaclonal variations (Prathanturarug et al. 2003).

Considering that turmeric variability in Brazil is low and that crop improvement is usually limited to germplasm selection, the introducion and evaluation of new genotypes is a priority to develop novel, better adapted materials. In 
this case, the introduction of genotypes from India can be an important source of genetic variation. Besides clonal selection, hybridization and seed formation in turmeric has also been achieved in India (Sasikumar 2005) and thus, it should be attempted in Brazil. Since most vegetativepropagated crops are highly heterozygous, hybridization could greatly enhance the genetic variability of the crop. Other recently developed approaches should also be as useful, such as the induction of genetically distinct shoots, protoplast fusion and genetic transformation via particle bombardment (Salvi et al. 2002, Shirgurkar et al. 2006).

\section{AKNOWLEDGEMENTS}

M.S.S. is grateful for the grant from Fundação de Amparo à Pesquisa do Estado de São Paulo (FAPESP). This study was also supported by funding from FAPESP (project \# 07/02895-4).

\title{
Divergência genética entre acessos brasileiros de cúrcuma utilizando descritores morfo-agronômicos
}

\begin{abstract}
RESUMO - A cúrcuma (Curcuma longa L.) é uma planta propagada vegetativamente que, além de ser utilizada como corante natural pela indústria alimentícia, apresenta diversos compostos biologicamente ativos. O melhoramento convencional da cultura é difícil, sendo usualmente limitado à seleção de germoplasma. O presente estudo avaliou a divergência genética entre os acessos de cúrcuma disponíveis no Brasil, utilizando sete descritores morfo-agronômicos. Foi verificada uma pequena divergência entre os acessos, embora alguns genótipos discrepantes pudessem ser identificados. Os acessos foram alocados em quatro agrupamentos principais, a serem considerados em futuros programas de melhoramento. A análise por variáveis canônicas indicou que alguns descritores colaboraram mais na discriminação dos acessos, enquanto que outros podem ser descartados. Os resultados fornecem subsídios importantes para o melhor uso e conservação da coleção.
\end{abstract}

Palavras-chave: Curcuma longa, planta medicinal, corante natural, recursos genéticos, análise multivariada.

\section{REFERENCES}

Cecílio-Filho AB, Souza RJ, Braz LT and Tavares M (2000) Cúrcuma: planta medicinal, condimentar e de outros usos potenciais. Ciência Rural 30: 171-175.

Chandra R, Desai AR, Govind S and Gupta PN (1997) Metrogliph analysis in turmeric $(C$. longa) germplasm in India. Scientia Horticulturae 70: 211-233.

Chaudhary AS, Sacham SK and Singh RL (2006) Studies on varietal performance of turmeric (Curcuma longa L.). Indian Journal of Crop Science 1: 1-2.

Cintra MMDF, Pinheiro JB and Sibov ST (2005) Genetic divergence among Curcuma longa L. accessions. Crop Breeding and Applied Biotechnology 5: 410-417.

Cruz CD (2001) Programa Genes - versão Windows. Editora UFV, Viçosa, 642p.

Cruz CD and Regazzi AJ (2001) Modelos biométricos aplicados ao melhoramento genético. Editora UFV, Viçosa, 390p.

Hossaim MA, Ishimine Y, Motomura K and Akamine H (2005) Effects of planting pattern and planting distance on growth and yield of turmeric (Curcuma longa L.). Plant Production Science 8: 95-105.
Lynrah PG, Barua PK and Chakrabarty BK (1998) Pattern of genetic variability in a collection of turmeric (Curcuma spp.) genotypes. Indian Journal of Genetics 58: 201-207.

Maia NB, Bovi OA, Duarte FR, Soria LG and Almeida JAR (1995) Influência de tipos de rizomas de multiplicação no crescimento de cúrcuma. Bragantia 54: 33-37.

Pinheiro JB, Zucchi MI, Teles FL and Azara NA (2003) Diversidade genética molecular em acessos de açafrão utilizando marcadores RAPD. Acta Scientiarum: Agronomy 25: 195-199.

Prathanturarug S, Soonthornchareonnon N, Chuakul W, Phaidee Y and Saralamp P (2003) High-frequency shoot multiplication in Curcuma longa L. using thidiazuron. Plant Cell Reports 21: 1054-1059.

Rao CR (1952) Advanced statistical methods in biometric research. John Wiley, New York, 390p.

Ravindran PN, Babu KN and Sivaranan K (2007) Turmeric: the genus Curcuma: medicinal and aromatic plants - industrial profiles. CRC press, Boca Raton, 484p.

Salvi ND, George L and Eapen S (2002) Micropropagation and field evaluation of micropropagated plants of turmeric. Plant Cell Tissue 68: 143-151. 
MS Sigrist et al.

Sasikumar B (2005) Genetic resources of curcuma: diversity, characterization and utilization. Plant Genetic Resources 3: 230-251.

Shirgurkar MV, Naik VB, Arnold S, Nadgauda RS and Clapham D (2006) An efficient protocol for genetic transformation and shoot regeneration of turmeric (Curcuma longa L.) via particle bombardment. Plant Cell Reports 25: 112-116.

Sigrist MS, Pinheiro JB, Azevado-Filho JA, Colombo CA, Bajay MM, Lima PF, Camilo FR, Sandhu S, Souza AP and Zucchi MI (2009) Development and characterization of microsatellite markers for turmeric (Curcuma longa). Plant Breeding (Online first) DOI: 10.1111/j.1439-0523.2009.01720.x
Singh Y, Mittal P and Katoch V (2003) Genetic variability and heritability in turmeric (Curcuma longa L.). Himachal Journal of Agricultural Research 29: 31-34.

Valois ACC, Paiva JR, Ferreira FR, Soares-Filho WS and Dantas JLL (2001) Melhoramento de espécies de propagação vegetativa. In Nass LL, Valois ACC, Melo IS and Valadares-Inglis MC (ed) Recursos genéticos e melhoramento - plantas. Fundação MT, Rondonópolis, p.283-292.

Yao Q, Yang K, Pan G and Rong T (2007) Genetic diversity of maize (Zea mays L.) landraces from Southwest China based on SSR data. Journal of Genetics and Genomics 34: 851-860. 